\title{
Penerapan Metode Usmani dalam Pembelajaran Al-Qur'an Santri TPQ Nurul Iman Garum Blitar
}

\author{
Abidatul Hasanah ${ }^{1}$ \\ ${ }^{1}$ Institut Agama Islam Negeri Tulungagung

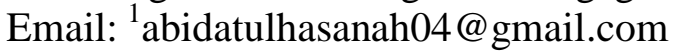

\section{Tersedia Online di \\ http://www.jurnal.unublitar.ac.id/ index.php/briliant}

\begin{tabular}{l}
\hline Sejarah Artikel \\
\hline Diterima pada 1 November 2017 \\
Disetuji pada 2 November 2017 \\
Dipublikasikan pada 13 \\
November 2017 Hal. $482-493$ \\
\hline
\end{tabular}

\section{Kata Kunci:}

usmani, membaca, menulis, menghafal, al quran,

\section{DOI:}

http://dx.doi.org/10.28926/briliant .v2i4.107

\begin{abstract}
Abstrak: Metode Usmani ini sebenarnya adalah metode dari ulama' salaf yang telah hilang, dikarenakan ada beberapa percobaan metodemetode baru yang belum pernah ada, yang mungkin bisa lebih mudah dan cepat dalam belajar membaca Al-Qur'an. Tetapi pada kenyataannya, banyak bacaan-bacaan Al-Qur'an yang masih menyalahi dan tidak sesuai dengan kaidah-kaidah tajwid. Untuk itulah penulis memilih Metode Usmani untuk dijadikan sebuah penelitian. Penelitian ini adalah kualitatif deskriptif, jenis penelitian studi kasus. Hasil penelitian menunjukkan Metode Usmani dalam pembelajaran menghafal Al-Qur'an metode ceramah, tanya jawab, latihan, eksperimen dan drill serta menggunakan teknik mengajar menggunakan Metode Usmani yaitu individual dan klasikal.
\end{abstract}

Kemauan mengubah budaya negatif menjadi budaya positif tumbuh setelah mereka benar-benar menyadari bahaya dari budaya negatif, baik sekarang, maupun masa depan. Dalam waktu yang bersamaan, mereka benar- benar menyadari manfaat atau dampak dari aplikasi budaya positif dalam kehidupan masyarakat sehari- hari, baik dalam jangka pendek, maupun jangka panjang. Untuk itu, mereka mesti berjuang keras melawan budaya negatif yang ada pada diri mereka sendiri, meskipun pada awalnya terasa sangat berat dan penuh tantangan (Qomar, 2012:21).

Melihat hal ini, kebiasaan yang buruk bisa diganti dengan kebiasaan yang baik. Yang mengingat jika kebiasaan yang buruk tidak dirubah akan menimbulkan dampak yang kurang baik pada diri kita sehari- hari. Tidak jauh dari halnya membiasakan hal- hal yang bermanfaat lebih berguna daripada melakukan sesuatu yang merugikan diri kita. Semua itu hanya bertujuan agar kita tidak jauh dari sang pencipta. Agar kebiasaan tersebut bisa berubah secara maksimal tentunya berasal dari pembelajaran dan pengajaran yang maksimal. Apalagi jika apa yang kita lakukan didasari agama yang kita anut dan berlandaskan dengan Al-Qur'an.

Pendidikan merupakan interaksi antara pendidik dengan peserta didik, untuk mencapai tujuan pendidikan, yang berlangsung dalam lingkungan pendidikan (Sukmadinata, 2003:10). Pendidikan merupakan kebutuhan yang penting bagi pertumbuhan manusia, karena dengan pendidikan memungkinkan sekali tumbuhnya kreatifitas dan potensi anak didik, yang pada akhirnya mengarahkan anak didik untuk mencapai satu tujuan yang sebenarnya. Untuk 
mencapai tujuan tersebut, salah satu bidang study yang harus dipelajari oleh peserta didik adalah pendidikan Agama Islam, yang dimaksudkan untuk membentuk peserta didik menjadi manusia yang beriman dan bertaqwa kepada Tuhan Yang Maha Esa.

Pengajaran adalah interaksi belajar dan mengajar. Pengajaran berlangsung sebagai proses saling mempengaruhi antara guru dan siswa. Di antara keduanya terdapat hubungan atau interaksi. Guru mengajar di satu pihak dan siswa belajar di lain pihak. Keduanya menunjukkan aktivitas yang seimbang, hanya berbeda peranannya saja (Hamalik, 1989:54). Menurut Hasibuan dan Moejdiono memberikan definisi mengajar adalah penciptaan sistem lingkungan yang memungkinkan terjadinya proses belajar (yaitu suatu usaha yang dilakukan oleh seseorang sehingga menyebabkan terjadinya perubahan tingkahlaku pada diri anak). Sistem lingkungan tersebut terdiri dari komponen-komponen yang saling mempengaruhi, antara lain tujuan, guru, siswa, materi, jenis kegiatan yang dilakukan, sarana dan prasarana belajar mengajar yang tersedia (Hasibuan \& Mudjiono, 1986:3). Oleh karena itu, pendidikan sangatlah penting, terutama pendidikan agama islam bagi kehidupan seseorang. Untuk mewujudkan kebiasaan anak-anak berperilaku keagamaan misalnya seperti sholat lima waktu, membaca Al-Qur'an, berdoa dan berbakti kepada orang tua maka yang paling utama bagi anak-anak itu untuk terlebih dahulu mempelajari Al-Qur'an. Karena Al-Qur'an itu sebagai pedoman hidup sehari-hari bagi umat manusia.

Keterpaduan proses belajar siswa dengan proses mengajar guru sehingga terjadi interaksi belajar mengajar (terjadinya proses pengajaran) tidak datang begitu saja dan tidak dapat tumbuh tanpa pengaturan dan perencanaan yang seksama. Pengaturan sangat diperlukan terutama dalam menentukan komponen dan variabel yang harus ada dalam proses pengajaran tersebut. Perencanaan dimaksudkan merumuskan dan menetapkan interelasi sejumlah komponen dan variabel sehingga memungkinkan terselenggaranya pengajaran yang efektif (Sudjana, 2004:29).

Metode mengajar adalah suatu teknik penyampaian bahan pelajaran kepada murid, dengan tujuan agar murid dapat menangkap pelajaran dengan mudah, efektif dan dicerna dengan baik. Hal ini dapat disimpulkan bahwa upaya dalam peningkatan kualitas pembelajaran sangat penting. Dalam pembahasan ini selain bisa membaca Al-Qur'an, juga diajarkan untuk bagaimana menulis AlQur'an yang benar agar dalam susunan penulisan tidak menyalahi arti dari konteks yang ada. Setelah sudah bisa membaca dan menulis Al-Qur'an alangkah baiknya kita bisa menghafal ayat- ayat Al-Qur'an minimal surat- surat pendek agar rasa cinta kita pada Al-Qur'an bertambah. Jika kita dalam keseharian memperbanyak ibadah khususnya membaca Al-Qur'an hati kita merasa tenang.

Oleh karena itu, pendidikan sangatlah penting, terutama pendidikan agama islam, bagi kehidupan seseorang. Untuk mewujudkan kebiasaan anak-anak berperilaku keagamaaan misalnya seperti sholat lima waktu, membaca Al-Quran, berdo'a, dan berbakti kepada orang tua. maka yang paling utama bagi anak-anak itu untuk terlebih dahulu mempelajari Al-Quran. Karena Al-Quran itu sebagai pedoman hidup sehari-hari bagi umat manusia (Amrullah, 2008:69). Seperti yang dijelaskan dalam hadits HR. Bukhari yang berbunyi:

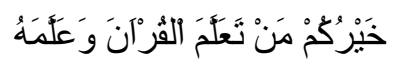

483 BRILIANT: Jurnal Riset dan Konseptual Volume 2 Nomor 4, November 2017 
Artinya: "sebaik-baik kamu sekalian adalah orang-orang yang mempelajari Al- Quran dan mengajarkanya”. (HR. Bukhari) (Sunarto, 93:619).

Dengan demikian, taman pendidikan Al-Quran (TPQ), sangatlah penting bagi anak-anak untuk belajar beragama terutama belajar membaca Al-Quran. Karena TPQ salah satu pendidikan lembaga non formal, untuk membantu keberhasilan lembaga pendidikan sekolah seperti Sekolah Dasar, Madrasah Ibtidaiyah, serta sekolah madrasah yang lebih tinggi lagi, terutam bidang studi yang berkaitan dengan agama islam.

Kalau kita lihat dalam proses perkembangan pendidikan agama di Indonesia, khususnya dalam pengajaran Al-Qur'an, tidak sedikit guru Al-Qur'an yang mengajarkan baca Al-Qur'an yang salah, yang tidak sesuai dengan kaidah tajwid yang telah diajarkan oleh Rasulullah SAW (Bachri, 2008:2). Di samping hal itu, ada salah satu hambatan yang menonjol dalam pelaksanaan pendidikan yaitu, dalam hal penggunaan metode pengajaran Al-Qur'an. Sehubungan dengan penggunaan metode tersebut, kini di Indonesia terdapat beberapa metode dalam pengajaran membaca Al-Qur'an, dimana awalnya hanya didasari atas penguasaan juz 'amma dan kini semakin bervariasi, dengan memperkaya dunia pendidikan di Indonesia setelah adanya panduan buku iqro' dan panduan buku An-Nahdiyah. Namun dengan demikian metode yang digunakan saat ini dalam membaca AlQur'an untuk anak pra sekolah masih terbatas pada buku sebagai sumber dan sekaligus media pengajaran. Sebagai akibat kondisi seperti ini, maka timbulah permasalahan bahwa tidak sedikit anak-anak sekolah merasa bosan belajar AlQur'an yang menerapkan metode dan media seperti itu sehingga anak mengalihkan perhatiannya kepada yang lain yang dianggap lebih mudah dan lebih memahamkan.

Mengantisipasai persoalan ini, maka akhir-akhir ini muncul sebuah metode ulama' salaf yang sebenarnya metode ini sudah lama, dikarenakan percobaan metode-metode baru yang belum ada, yang mungkin bisa lebih mudah dan cepat dalam belajar membaca Al-Qur'an. Namun pada kenyataan sebaliknnya, banyak bacaan-bacaan Al-Qur'an yang menyalahi dan keluar dari kaidah-kaidah ilmu tajwid, yaitu Metode Usmani, suatu metode yang mempunyai karakteristik dan spesifikasi tertentu yang membedakan dengan metode lain (Lembaga pendidikan Al-qur'an, 2010:1). Selain membaca, anak sebaiknya juga terampil dalam menulis Al-Qur'an, hal ini menjadi salah satu bagian dari peguasaan yang harus dimiliki anak. Pembelajaran menulis Al-Qur'an yang dimulai sejak dini diharapkan akan memberikan hasil yang lebih baik. Untuk menjembatani itu, diperlukan upaya yang serius dari guru agar anak mampu dan terampil dalam menulis Al-Qur'an benar, tepat, dan rapi.

Melihat tersebut, maka peneliti merasa tertarik untuk meneliti hal itu karena merupakan salah satu bentuk upaya untuk ikut serta menjaga dan memelihara keaslian, kesucian dan kehormatan Al-Qur'an baik dari aspek bacaan maupun tulisan (rosm)nya, serta upaya mendukung efektifitas dalam pengembangan kemampuan membaca Al-Qur'an pada anak sekolah. Dan peneliti memilih TPQ Nurul Iman Garum sebagai objek penelitian karena TPQ nurul iman merupakan TPQ pusat dalam pembelajaran usmani. Dalam pembelajaran yang dihasilkan cukup berkualitas disbanding dengan TPQ lainya, padahal metode 
ataupun langkah-langkah yang diajarkan sama. Sehingg tujuan penelitian ini adalah (1) Untuk mengetahui penerapan Metode Usmani dalam pembelajaran membaca Al-Qur'an santri TPQ Nurul Iman Garum Blitar. (2) Untuk mengetahui penerapan Metode Usmani dalam pembelajaran menulis Al-Qur'an santri TPQ Nurul Iman Garum Blitar. (3) Untuk mengetahui penerapan Metode Usmani dalam pembelajaran menghafal Al-Qur'an santri TPQ Nurul Iman Garum Blitar..

\section{METODE}

Penelitian ini terfokus pada penerapan metode usmani dalam pembelajaran Al-Qur'an santri TPQ Nurul Iman. Untuk mengungkap subtansi penelitian ini diperlukan pengamatan yang mendalam dan dengan latar belakang yang alami. Dengan demikian pendekatan yang diambil adalah pendekatan kualitatif. Tujuan penelitian ini adalah mendeskripsikan penerapan metode usmani dalam pembelajaran Al-Qur'an santri TPQ Nurul Iman, maka jenis rancangan penelitian ini yang sesuai adalah penelitian kualitatif. Metode kualitatif adalah penelitian yang bermaksud untuk memahami fenomena tentang apa yang dialami oleh subjek penelitian misalnya perilaku, persepsi, motivasi, tindakan dll. Secara holistik, dan dengan cara deskripsi dalam bentuk kata-kata dan bahasa, pada suatu konteks khusus yang alamiah dan dengan memanfaatkan berbagai metode alamiah (Moleong, 2005:6).

Lokasi dalam penelitian ini adalah di TPQ Nurul Iman Garum kabupaten Blitar, hal ini dikarenakan TPQ Nurul Iman merupakan pusat dari pembelajaran metode usmani. Teknik pengumpulan data yang digunakan adalah dengan melakukan observasi partisipan, wawancara mendalam, dan dokumentasi. Analisis data dalam penelitian kualitatif, dilakukan setelah pengumpulan data analisis dilakukan dengan menggunakan teknik yang dikembangkan Miles, Hubberman \& Saldana (2014), yaitu (1) Reduksi data, (2) Penyajian Data, dan (3) Penarikan Kesimpulan.

\section{HASIL}

\section{Penerapan metode usmani dalam pembelajaran membaca Al-Qur'an}

Berdasarkan konteks penerapan metode usmani dalam pembelajaran membaca Al- Qur'an, peneliti melakukan observasi secara langsung ke tempat penelitian yakni, di TPQ Nurul Iman Garum Blitar pada hari Selasa 21 Februari 2017. Peneliti datang ke tempat penelitian pada pukul 15.00 WIB, tepatnya setengah jam sebelum pembelajaran dimulai yaitu pukul 15.30 WIB. Dalam waktu setengah jam tersebut peneliti memanfaatkan waktu sebaik mungkin untuk mengetahui bagaimana keadaan sebelum pembelajaran di TPQ dimulai. Selain itu peneliti juga ingin mengetahui persiapan yang dilakukan ustadzah sebelum melakukan pembelajaran. Pada pukul 15.30 WIB para santri masuk kelas untuk melaksanakan pembelajaran yang akan berlangsung.

Waktu itu saya masuk di kelas Nur Ayni Mukaromah yaitu dikelas 6 yang santrinya setingkat dengan kelas 4-6 SD/MI. Berdasarkan observasi yang saya lihat Ustadzah Ayni benar-benar menerapkan metode dan strategi yang sesuai dengan tahap-tahap pembelajaran yang ada pada pedoman usmani. Pada waktu itu dengan sifat keibu-ibuannya Ustadzah Ayni masuk kelas dengan wajah yang sangat hangat menyapa santri dengan mengucapkan salam. Secara spontan santri menjawab salam dengan penuh semangat seolah-olah mencerminkan para 
santri siap untuk menerima pembelajaran yang akan disampaikan hari itu. Sebelum pembelajaran dimulai ustadzah terlebih dahulu menyiapkan seluruh santri untuk tenang dan duduk dengan rapi ditempat masing-masing. Setelah para santri duduk dengan rapi, ustadzah membaca hadroh Al-Fatihah dan para santri mengikuti instruksi yang telah ustadzah berikan saat itu juga santri dengan lantang membaca surah Al-Fatihah. Setelah membaca surah Al-Fatihah melanjutkan do'a awal pembelajaran yaitu:

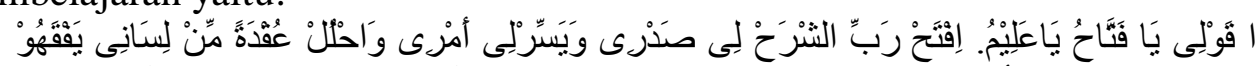

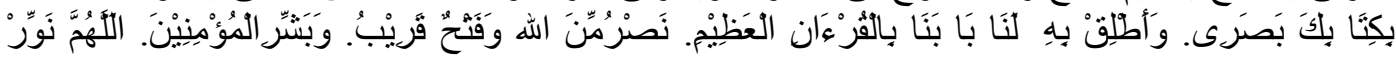

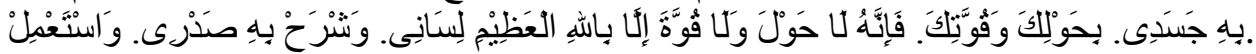

Dilanjutkan dengan membaca do'a

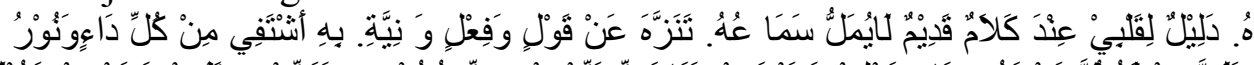

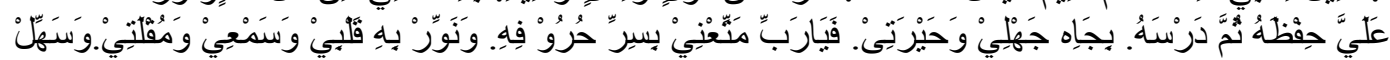

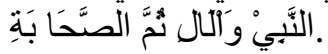

Setelah selesai membaca do'a, sebelum memulai pembelajaran ustadzah terlebih dahulu mengabsen kehadiran para santri. Ketika nama santri yang di sebutkan, santri berdiri dan maju ke depan untuk mengumpulkan buku prestasi. Setelah ustadzah selesai mengabsen, ustadzah menanyakan kabar para santrinya dan memberi sedikit apersepsi seperti menanyakan " Tadi siapa yang berangkat tidak berjabat tangan denga orang tuanya?" santri bersaut-sautan menjawab pertanyaan dari Ustadzah Ayni ada yang menjawab sudah ada yang menjawab belum. Setelah Ustadzah Ayni tahu alasan dari santri yang sudah dan belum berjabat tangan, Ustadzah Ayno memberikan sedikit pengarahan dampak ataupun fadhilah ketika berjabat tangan kepada orang tua sebelum berangkat mencari ilmu ataupun keluar dari rumah.

Kegiatan apersepsi dilakukan sekitar 5 menit dan dilanjutkan dengan pengulangan materi yang telah disampaikan pada pertemuan sebelumnya. Pengulangan materi ini dilakukan dengan cara klasikal, teknik klasikal merupakan teknik pembelajaran yang cukup efesien karena teknik ini tidak membutuhkan waktu yang lama dan mempermudah ustadzah dalam proses pengulangan materi. Dengan adanya pengulangan materi para santri diharapkan lebih memahami materi dan tetap mengingat materi yang telah disampaikan.

Setelah kegiatan pengulangan materi selesai, kegiatan dilanjutkan dengan pemberian materi baru dengan bantuan alat peraga. Ustadzah Ayni dengan kesiapanya membacakan materi beikutnya yang dilakukan secara klasikal. Kemudian santri menirukan apa yang Ustadzah ucapkan sesuai meteri yang akan dilanjutkan. Pelafalan yang dilakukan secara berulang-ulang agar santri dapat melafalkan makhraj dengan benar.

Melihat santri yang sudah faham dengan materi yang baru diajarkan, Ustadzah Ayni mengakhiri pembelajaran yang disampaikan dan dilanjutkan dengan nderes secara individual sesuai dengan halaman yang akan disorogan. Santri dengan semangat membuka jilidnya dan mulai membaca. Sekitar 5 menit kegiatan nderes, Ustadzah Ayni memanggil satu persatu nama santri sesuai dengan buku prestasi yang sudah dikumpulkan.

Sebelum pulang, Ustadzah Sita kembali lagi mengulang pelajaran yang baru disampaikan. Sistem yang digunakan yaitu sistem drill, sistem drill yaitu suatu cara mengajar dengan memberikan latihan-latihan terhadap apa yang telah 
dipelajari santri sehingga memperoleh suatu keterampilan tertentu. Kata latihan ini santri mengulang-ngulang materi yang telah disampaikan oleh ustadzah. Ustadzah mencontohkan bacaan-bacaan yang berbeda-beda tetapi masih dalam konteks materi yang sama, sehingga santri memahami betul materi yang telah disampaikan walaupun dalam bacaan yang berbeda.

Sistem drill dilakukan sekitar 5-7 menit menjelang pulang, setelah itu ustadzah menyiapkan dan menenangkan para santri untuk persiapan pulang. Ketika santri sudah duduk rapi dan tenang Ustadzah Ayni memipin do'a pulang dan dengan lantang para santri berdoa yaitu dengan lafad:

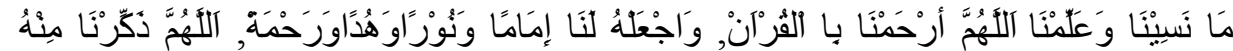

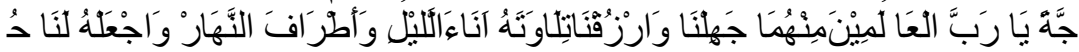

Setelah itu Ustadzah Ayni memberikan pesan-pesan kepada santri seperti "Nanti kalu pulang hati-hati dijalan, gak usah mampir kerumah temanya apalagi bermain bermain dulu. Langsung kerumah masing-masing ya?" para santri menjawab "Iya ustadzah". Kemudian ustadzah Ayni mengucapkan salam, setelah para santri menjawab salam dari ustadzah, mereka berbaris untuk berjabat tangan dengan ustadzah dan pulang dengan tertib.

\section{Penerapan metode usmani dalam pembelajaran menulis Al-Qur'an.}

Kegiatan yang selalu dilakukan santri setiap hari yaitu belajar membaca namun khusus hari jum'at kegiatan yang dilakukan para santri mulai dari kelas 17 yaitu menulis. Kegiatan menulis ini berguna untuk mengenalkan dan melatih bagaimana caranya menulis huruf hijaiyah. Agar santri tidak hanya bisa membaca namun juga bisa menulis. Peneliti melakukan observasi langsung ke tempat penelitian yang dilaksanakan pada hari jum'at tanggal 3 Maret pada pukul 16.00 WIB. Seperti biasanya para santri masuk kelas kemudian setelah ustadzah datang, ustadzah mengucapkan salam dengan semangat santri menjawab salam. Melihat anak-anak yang masih gundah ustadzah langsung menenangkan para santri untuk persiapan berdo'a bersama. Setelah semua tenang ustadzah memimpin do'a kemudian para santri berdo'a dengan fasih dan lancar. Sekitar 5 menit santri sudah berdo'a, kemudian ustadzah melakukan apresiasi dan absensi sambil santri mengumpulkan buku prestasi.

Sebelum melanjutkan ke materi berikutnya ustadzah mengulang pelajaran yang kemarin. Sebelum mengulang materi ustadzah mencoba bertanya kepada santri "Siapa yang masih ingat dengan pelajaran minggu lalu? Jum'at lalu kita belajar menulis apa? Ada yang ingat?" salah satu santri ada yang menjawab "Ingat bu, kemarin belajar menulis huruf yang ustadzah contohkan dipapan tulis". Dengan cepatnya ustadzah mengangkat jempolnya dan berkata "Bagus, masih mengingat materi yang sudah ustadzah ajarkan. Sekarang kita melanjutkan materi selanjutnya. Hayo sekarang bukunya dikeluarkan semua kita belajar menulis bersama." Serentak para santri mengeluarkan buku dan alat tulis masing-masing.

Ketika para santri sudah siap, ustadzah menulis materi yang akan dipelajari hari itu. Dengan antusiasnya para santri memperhatikan apa yang sedang ustadzah jelaskan didepan. Setelah penjelasan ustadzah selesai, ustadzah menyuruh salah satu santri untuk maju kedepan menirukan tulisan yang baru ustadzah jelaskan untuk mengukur santri sudah faham atau belum atas materi 
yang baru saja ustadzah jelaskan. Melihat santri sudah faham dengan materi yang baru, ustadzah menyuruh para santri untuk menulis dibuku masing-masing. Dengan tlatennya ustadzah melihat satu persatu proses penulisan para santri. Jika ada yang salah dengan kalemnya ustadzah membantu santri untuk menyelesaikannya.

Jika ada yang sudah selesai, santri membawa bukunya ke depan untuk dikoreksi. Setelah para santri selesai semua dan sudah dikoreksi, ustadzah mengmebalikan buku para santri. Agar para santri lebih faham ustadzah meberi PR santri sesuai dengan materi yang baru dipelajari dan ditulis di buku tulis. Selain materi menulis ustadzah juga memberikan materi fasholatan. Diantaranya yaitu bagiamana bacaan sholat dan gerakannya, bacaan itu diulang-ulang sampai para santri mulai hafal. Kemudian santri diberi waktu sekitar 5 menit untuk menghafalkan bacaan yang ustadzah tentukan siapa yang sudah hafal santri menyetorkan hafalanyya ke ustadzah.

Para santri sudah menyetorkan hafalannya ke ustadzah kemudian santri dengan semangatnya mempersiapkan diri untuk pulang. Ustadzah menangkan para santri, ketika santri sudah tenang ustadzah memberikan apersepsi pesanpesan kepada santri untuk hati-hati dijalandan selalu mengingat materi yang telah disampaikan. Kemudian dipandu untuk berdo’a.

\section{Penerapan metode usmani dalam pembelajaran menghafal AL-Qur'an}

Selain membaca dan menulis Al-Qur'an pembelajaran yang akan diberikan yaitu tentang menghafal. Kegiatan menghafal ini sangat bermanfaat dalam kehidupan santri sehari-hari. Melancarkan santri saat melakukan ibadah yang dilakukan. Peneliti melakukan observasi ke tempat penelitian yang dilaksanakan hari Senin pada tanggal 6 Maret 2016 pukul 16.00 WIB. Peneliti langsung menuju kelas 7 untuk melihat proses belajar mengajar menghafal AlQur'an. Peneliti mengamati proses yang ada di dalam kelas 7 sampai selesainya pembelajaran. Dalam proses kegiatan yang dilakukan kelas ini tidak jauh beda dengan kelas lain. Datang berdoa, kemudian ustadzah masuk mengulang materi yang kemarin setelah itu diberi materi baru diulang-ulang dan sebagainya. Namun, untuk kelas 7 kalau kelas 1-6 mengenal huruf dan sifat makhroj. Untuk kelas 7 yaitu mempelajari Al-Qur'an, mempelajari tajwid dan menyetorkan hafalan-hafalan yang sudah menjadi target kelas 7 .

\section{PEMBAHASAN}

\section{Penerapan Metode Usmani dalam Pembelajaran Membaca Al-Qur'an Santri TPQ Nurul Iman Garum Blitar}

Berdasarkan hasil temuan penelitian tentang pembelajaran membaca AlQur'an dengan Metode Usmani, telah ditemukan beberapa data yang peneliti butuhkan baik dari hasil observasi, wawancara maupun dokumentasi. Maka peneliti mengklarifikasikan dengan teori-teori yang sudah dipaparkan dengan temuan hasil penelitian.

Dari hasil observasi dan wawancara bahwa dalam proses pembelajaran Usmani ustadzah melakukan beberapa tahapan mengajar metode Usmani yaitu: salam, hadroh fatihah, do'a awal pelajaran, menangkan santri agar siap menerima pelajaran, mengulangi materi yang kemari, menjelaskan pokok materi baru beserta 
contohnya. Latihan secara bersama dan kelompok, latihan individu, menyampaikan pesan moral, do'a dan salam.

Tahapan mengajar secara khusus sebagai berikut: (1) Pembukaan: Salam, Hadroh fatihah, Do'a sebelum pelajaran; (2) Appersepsi: Usaha agar santri tenang, senang, dan bahagia dalam belajar, Mengulang materi pelajaran yang telah diajakan sebelumnya; (3) Penanaman konsep: Menerangkan/menjelaskan mengenai materi pelajaran baru dan memberi contoh, Mengusahakan murid memahami materi pelajaran (4) Pemahaman : Latihan secara bersama-sama ataupun kelompok; (5) Keterampilan, (6)Penutup : Pesan moral pada murid, Do'a penutup, Salam.

Jadi, hasil temuan penelitian ini antara hasil observasi yang peneliti lakukan dengan teori yang ada sudah sesuai yaitu di TPQ Nurul Iman Garum dalam pembelajaran membaca Al-Qur'an sesuai dengan tahap-tahap mengajar Metode Usmani. Di TPQ Nurul Iman ini juga menerapkan prinsip dasar pembelajaran Metode Usmani, ada dua prinsip yaitu prinsip dasar bagi para ustadzah dan prinsip dasar bagi santri.

Prinsip dasar pembelajaran Metode Usmani yaitu: (1) Prinsip dasar bagi guru pengajar: Dak-Tun (Tidak Boleh Menuntun). Dalam mengajar Metode Usmani, guru tidak diperbolehkan menuntun namun hanya sebagai pembimbing, Ti-Was-Gas (Teliti, Waspada dan Tegas). Dalam mengajarkan ilmu baca AlQur'an sangatlah dibutuhkan ketelitian dan kewaspadaan seorang guru. Sebab akan saat berpengaruh atas kefasihan dan kebenaran murid dalam membaca AlQur'an. (2) Prinsip dasar bagi murid: CBSA + M (Cara Belajar Santri Aktif dan Mandiri). Dalam belajar membaca Al-Qur'an, murid sangat dituntut keaktifan dan kemandiriannya. Sedangkan guru hanya sebagai pembimbing dan motivator, LSB (Lancar, Benar dan Sempurna) dalam membaca Al-Qur'an, murid dituntut untuk membaca secara LBS.

Selain menggunaan prinsip-prinsip tersebut, Di TPQ Nurul Iman ini juga menerapkan beberapa metode pembelajaran yaitu metode ceramah, tanya jawab , demontrasi, eksperimen dan latihan. Beberapa macam tersebut berupa metode ceramah yang merupakan "... metode mengajar paling tradisional dan telah lama dijalankan dalam pendidikan. Sejak dahulu guru dalam usaha mentransfer pengetahuannya pada siswa, ialah secara lisan atau ceramah Kemudian diikuti dengan metode demonstrasi. Siswa tidak melakukan percobaan, hanya melihat saja apa yang dikerjakan oleh guru (Yoto \& Rahman, 2001:91). salah satu cara mengajar, dimana siswa melakukan suatu percobaan tentang sesuatu hal, mengamati prosesnya serta menuliskan hasil percobaan tentang sesuatu hal, mengamati prosesnya serta menuliskan hasil percobaannya kemudian hasil pengamatan itu disampaikan ke kelas dan dievaluasi oleh guru (Yoto \& Rahman, 2001:88).

Selanjutnya metode pembelajaran dijabarkan ke dalam teknik dan gaya pembelajaran. Dengan demikian, tehnik pembelajaran dapat diartikan sebagai cara yang dilakukan seseorang dalam mengimplementasikan metode secara spesifik. teknik-teknik yang dilakukan di TPQ Nurul Iman ini menerapkan beberapa teknik mengajar metode usmani agar proses pembelajarannya berjalan dengan baik. Adapapun tekhnik yang digunakan yaitu individual/sorogan dan kalsikal.

Tekhnik tersebut bertujuan agar dalam proses belajar mengajar dapat berjalan dengan baik, oleh karena itu maka dipilihlah strategi tersebut yang 
diantaranya: (1) Individual/Sorogan, yaitu mengajar dengan cara satu persatu sesuai dengan pelajaran yang dipelajari atau dikuasai murid. Sedangkan murid yang sedang menunggu giliran atau sesudah mendapatkan giliran, diberi tugas menulis, membaca dan atau yang lainnya. Strategi ini diterapkan bila jumlah murid tidak memungkinkan untuk dijadikan klasikal dan buku usmani masingmasing murid berbeda antara yang satu dengan yang lain. (2) Klasikal yaitu mengajar dengan cara memberikan materi pelajaran secara bersama-sama kepada sejumlah murid dalam satu kelas. Strategi ini bertujuan untuk menyampaikan pelajaran secara garis besar dan prinsip-prinsip yang mendasarinya serta memberi motivasi/dorongan semangat belajar murid.

Untuk mengetahui keberhasilan murid dalam mengajar Al-Qur'an dengan Metode Usmani, guru harus mengadakan evaluasi/ tes kemampuan membaca setiap murid yaitu: (1) test pelajaran,Yaitu test/evaluasi yang dilakukan oleh guru kelas terhadap murid yang telah menyelesaikan pelajarannya dengan ketentuan murid harus LBS dalam membaca. Evaluasi/test dilakukan setiap saat/pertemuan tergantung kemampuan murid. (2) Test kenaikan juz, yYaitu test/evaluasi yamg dilakukan oleh kepala sekolah (atau guru ahli ynag ditunjuk), terhadap murid yang telah menyelesaikan juz masing-masing. Test/evaluasi dilakukan setiap saat tergantung kemampuan murid dengan syarat murid tersebut harus telah menyelesaikan dan menguasai juz/modul yang telah dipelajari. (3) Khotam pendidikan Al-Qur'an, Setelah menyelesaikan dan menguasai semua pelajaran, maka murid telah siap untuk mengikuti test/tashih akhir, dengan syarat: (1) Mampu membaca Al-Qur'an dengan tartil. (2) Mengerti dan menguasai ilmu tajwid. (3) Dapat mewaqofkan dan mengibtida'kan bacaan Al-Qur'an dengan baik.

\section{Penerapan Metode Usmani dalam Pembelajaran Menulis Al-Qur'an Santri TPQ Nurul Iman Garum Blitar}

Berdasarkan hasil temuan penelitian tentang pembelajaran menulis AlQur'an dengan Metode Usmani, telah ditemukan beberapa data yang peneliti butuhkan baik dari hasil observasi, wawancara maupun dokumentasi. Maka peneliti mengklarifikasikan dengan teori-teori yang sudah dipaparkan dengan temuan hasil penelitian.

Dari hasil observasi dan wawancara bahwa dalam proses pembelajaran Usmani ustadzah melakukan beberapa tahapan mengajar Metode Usmani yaitu: salam, hadroh fatihah, do'a awal pelajaran, menangkan santri agar siap menerima pelajaran, mengulangi materi yang kemarin, menjelaskan pokok materi baru beserta contohnya. Latihan secara bersama dan kelompok, latihan individu, menyampaikan pesan moral, do'a dan salam. Jadi, hasil temuan penelitian ini antara hasil observasi yang peneliti lakukan dengan teori yang ada sudah sesuai yaitu di TPQ Nurul Iman Garum dalam pembelajaran menulis Al-Qur'an sesuai dengan tahap-tahap mengajar Metode Usmani. Di TPQ Nurul Iman ini juga menerapkan prinsip dasar pembelajaran Metode Usmani, ada dua prinsip yaitu prinsip dasar bagi para ustadzah dan prinsip dasar bagi santri.

Dalam menulis AL-Qur'an, murid dituntut untuk terampil dalam menulis huruf hijaiyah. Guru harus terampil menulis khususnya menulis huruf hijaiyah dan guru tetap mendampingi dalam berlangsungnya pembelajaran. Adapaun bagi murid yang perlu disiapkan yaitu kesiapan murid saat menerima pelajaran dan 
mngerjakan apa yang sudah ditugaskan oleh guru semisal mengerjakan PR. Jadi disetiap akhir pelajaran guru memberikan evaluasi melalui PR tersebut. Seperti J.J. Hasibuan \& Moedjiono (2010:40) pada tahap sesudah pengajaran mengatakan bahwa Beberapa perbuatan guru yang nampak pada tahap sesudah mengajar, antara lain: (a) Menilai pekerjaan siswa. (b) Membuat perencanaan untuk pertemuan berikutnya. (c) Menilai kembali proses belajar-mengajar yang telah berlangsung.

Selain itu teknik yang digunakan yaitu sorogan, klasikal, metode ceramah, tanya jawab, latihan, eksperimen. Metode demonstrasi yang dimaksud seperti sebagaimana yang diungkapkan oleh Mufarrokah (2009:89) adalah suatu metode mengajar dengan jalan guru atau orang lain (yang sengaja diminta) atau siswa sendiri memperlihatkan atau mempertunjukkan gerakan-geraka, suatu proses (bekerjanya sesuatu, megerjakan tindakan) dengan prosedur yang benar disertai dengan keterangan-keterangan kepada seluruh kelas. Metode eksperimen sebagaimana dikemukakan oleh Mufarrokah (2009:97) adalah cara penyajian bahan pelajaran dimana siswa melakukan percobaan dan mengalaminya sendiri, membuktikan sendiri, melakukan sendiri, mengikuti suatu proses, mengamati obyek, menganalisa, menarik kesimpulan sendiri tentang suatu obyek, keadaan atau proses sesuatu.

Untuk mengetahui keberhasilan murid dalam mengajar Al-Qur'an dengan Metode Usmani, guru harus mengadakan evaluasi/ tes kemampuan menulis setiap murid yaitu: Penilaian dilakukan setiap kali pertemuan dan dicatat di buku prestasi santri, Penilaian pertengahan jilid, Penilaian akhir jilid atau tashih.

\section{Penerapan Metode Usmani dalam Pembelajaran Menghafal Al-Qur'an Santri TPQ Nurul Iman Garum Blitar}

Berdasarkan hasil temuan penelitian tentang pembelajaran menghafal AlQur'an dengan Metode Usmani, telah ditemukan beberapa data yang peneliti membutuhkan baik dari hasil observasi, wawancara maupun dokumentasi. Maka peneliti mengklarifikasikan dengan teori-teori yang sudah dipaparkan dengan temuan hasil penelitian.

Dari hasil observasi dan wawancara bahwa dalam proses pembelajaran Usmani ustadzah melakukan beberapa tahapan mengajar Metode Usmani yaitu: salam, hadroh fatihah, do'a awal pelajaran, menangkan santri agar siap menerima pelajaran, mengulangi materi yang kemari, menjelaskan pokok materi baru beserta contohnya. Latihan secara bersama dan kelompok, latihan individu, menyampaikan pesan moral, do'a dan salam.

Jadi, hasil temuan penelitian ini antara hasil observasi yang peneliti lakukan dengan teori yang ada sudah sesuai yaitu di TPQ Nurul Iman Garum dalam pembelajaran membaca Al-Qur'an sesuai dengan tahap-tahap mengajar Metode Usmani. Di TPQ Nurul Iman ini juga menerapkan prinsip dasar pembelajaran Metode Usmani, ada dua prinsip yaitu prinsip dasar bagi para ustadzah dan prinsip dasar bagi santri.

Dalam membaca Al-Qur'an, murid dituntut untuk menghafal secara LBS.mTeknik yang digunakan dalam penerapan menghafal ini yaitu sorogan, klasikal, drill dan individual Metode ceramah, tanya jawab, latihan dan eksperimen. Dari berbagai macam metode tersebut untuk proses eksperimen ini, 
peserta didik diberikan kesempatan berulang-ulang melalui metode jibril atau drill. Teknik jibril atau dapat disebut drill merupakan cara mengajar dimana mengajar dimana siswa melaksanakan kegiatan-kegiatan latihan agar siswa memiliki ketangkasan atau keterampilan yang lebih tinggi dari apa yang telah dipelajari.

Untuk mengetahui keberhasilan murid dalam mengajar Al-Qur'an dengan Metode Usmani, guru harus mengadakan evaluasi/tes kemampuan menulis setiap murid yaitu: Penilaian dilakukan setiap kali pertemuan dan dicatat di buku prestasi santri dan penilaian dilakukan saat akan kenaikan kelas dan diwisuda

Kegiatan evaluasi ini sangat diperlukan dalam pembelajaran. Hal ini sesuai dengan pernyataan Arifin (2009:9-10) bahwa evaluasi pembelajaran adalah suatu proses atau kegiatan yang sistematis, berkelanjutan, dan menyeluruh dalam rangka pengendalian, penjaminan, dan penetapan kualitas (nilai dan arti) pembelajaran terhadap berbagai komponen pembelajaran, berdasarkan pertimbangan dan kriteria tertentu, sebagai bentuk pertanggungjawaban guru dalam melaksanakan pembelajaran.

\section{KESIMPULAN}

Berdasarkan hasil penelitian dan pembahasan maka dapat disimpulkan sebagai berikut: (1) Penerapan Metode Usmani dalam pembelajaran membaca AlQur'an santri TPQ Nurul Iman Garum Blitar yaitu menggunakan beberapa metode pembelajaran diantaranya metode ceramah, tanya jawab, latihan, eksperimen. Dan menggunakan teknik mengajar menggunakan Metode Usmani yaitu individual dan klasikal. (2) Penerapan Metode Usmani dalam pembelajaran menulis AlQur'an santri TPQ Nurul Iman Garum Blitar yaitu Hal-hal yang perlu dipersiapkan dalam pembelajaran menulis Al-Qur'an yaitu: metode ceramah, tanya jawab, latihan, eksperimen. Dan menggunakan teknik mengajar menggunakan Metode Usmani yaitu individual dan klasikal. (3) Penerapan Metode Usmani dalam pembelajaran menghafal Al-Qur'an santri TPQ Nurul Iman Garum Blitar yaitu menggunakan beberapa metode pembelajaran diantaranya metode ceramah, tanya jawab, latihan, eksperimen dan drill. Dan menggunakan teknik mengajar menggunakan Metode Usmani yaitu individual dan klasikal.

\section{SARAN}

Bagi lembaga untuk selalu mempertahankan dan meningkatkan kualitas pembelajaran membaca, menulis dan menghafal Al-Qur'an dengan Rosm Usmani. Bagi kepala sekolah sebaiknya menambah mutu dan kualitas belajar mengajar membaca, menulis dan menghafal Al-Qur'an sesuai dengan metode usmani, dalam kepengurusan sebaiknya lebih diperatikan lagi agar terorganisir dengan baik. Bagi ustadzah jangan berhenti di PGPQ saja namun pembelajaran lebih ditingkatkan lagi dalam jenjang lebih tinggi yaitu PTQ dan PTQMU. Lebih disiplin lagi dalam kehadirannya.

\section{DAFTAR RUJUKAN}

Amrullah, F. 2008. Ilmu Al-Quran Untuk Pemula. Jakarta: CV Artha Rivera. Arifin, Z. 2009. Evaluasi Pembelajaran Prinsip, Teknik, Prosedur. Bandung: PT Remaja Rosdakarya. 
Bachri, S. 2008. Materi Pendidikan Guru Pengajar Al-Qur'an. Blitar: Pon. Pes Nurul Iman.

Hamalik, O. 1989. Proses Belajar Mengajar. Bandung: Sinar Baru.

Hasibuan \& Mudjiono. 1986. Proses Belajar Mengajar. Bandung: PT Remaja Rosda Karya.

Lembaga pendidikan Al-qur'an (LPQ). 2010. Buku Panduan pendidikan Guru Pengajar Al-qur'an (PGPQ). Blitar: Pon.Pes Nurul Iman.

Miles, M.B., Huberman, A.M., \& Saldana, J. 2014. Qualitative Data Analysis: A Methods Sourcebook. Third Edition. SAGE Publication Asia-Pacific Pte. Ltd. Singapore.

Moleong, LJ. 2005. Metodologi Penelitian Kualitatif. Bandung: PT Remaja Rosdakarya.

Mufarrokah, A. 2009. Strategi Belajar Mengajar. Yogyakarta: Teras.

Qomar, M. 2012. Kesadaran Pendidikan Sebuah Penentu Keberhasilan Pendidikan. Jogjakarta: Ar- Ruzz Media.

Sudjana, N. 2004. Dasar-Dasar Proses Belajar Mengajar. Bandung: Sinar Baru Algensindo.

Sukmadinata, NS. 2003. Landasan Psikologi Proses Pendidikan. Bandung: PT Remaja Rosdakarya.

Sunarto, A. 1993. Tarjamah Shahih Bukhari Jilid VI. Semarang: CV Asy Syifa'.

Yoto \& Rahman, S. 2001. Manajemen Pembelajaran. Malang: Yanizar Group. 